\title{
血液透析患者のエンドトキシン抗体の測定と光の臨床的意義
}

\author{
安達高久山上征二岸本武利前川正信 \\ 川村 正 喜* \\ 大阪市立大学泌尿器科 PL 病院泌尿器科*
}

key words : endotoxin antibody, hemodialysis, hemodialysis patient, ELISA, high-flux membrane

〈要旨〉

近年, 透析液の細菌やエンドトキシンによる污染の増強と high-flux 膜の使用により, エンドトキシンのサブユニッ トやフラグメントが患者血液内に侵入している危険性が指摘されている. そこで著者は, avidin-biotin の強い親和性 と抗原抗体反応の特異性を利用した enzyme-linked immunosorbent assay (ELISA) 法を用いて, 透析患者血液中の エンドトキシン抗体を測定した。 まず最初に透析液中の細菌の分離・培養と同定, さらにこれより温フェノール法を 用いてエンドトキシンの抽出を行った. さらにこの抽出したエンドトキシンとE. coli J-5 のエンドトキシンが, ELISA 法において交差反応を示すことを確認した. 次に加熱処理した菌体で免疫した家鬼より得た標準エンドトキシン抗体 について, immuno-blotting を行い抗体価の確認を行った。 さらにこの標準エンドトキシン抗体を用いて ELISA 法 による検量線を作製し, 抗体陽性の規準を設定した, 以上の予備実験に基づいて, 透析患者 101 名と健康対照者 21 名 について E. coli J-5 のエンドトキシンを抗原として血液中のエンドトキシン抗体を測定した.

結果は, 正常対照群では 21 名中 4 名 (19\%), 従来の膜を使用した群では 54 名中 14 名 (26\%) が抗体陽性であり, 一方 high-flux 膜使用患者では 47 名中 28 名 $(60 \%)$ が抗体陽性であり, $\chi^{2}$ (カイ自乗) 検定の結果, 前 2 者に比較 し有意に高值を示した。この結果は, 特に high-flux 膜使用患者において, 透析液中のエンドトキシンが血液内に侵 入していることを強く示唆するものであった.

\section{Detection of endotoxin antiboby in the hemo-dialysis patient and its clinical significance}

Takahisa Adachi, Seiji Yamagami, Taketoshi Kishimoto, Masanobu Maekawa, Masaki Kawamura* Department of Urology, Osaka City University ; Department of Urology, PL Hospital*

Recently, with the frequent use of high-flux membranes, bacterial contamination and endotoxin pollution of the dialysate have become an important issue in hemodialysis (HD), and the hazards of subunits or small fragments of endotoxins passing through the membrane by back diffusion or back filtration from the dialysate into the blood of HD patients have been increasingly discussed. In this study, antibodies against endotoxins in the blood of HD patients were measured by means of the ELISA method, which is more sensitive and specific to endotoxins than conventional methods.

Initially, the bacteria in the dialysate were collected and identified. Endotoxins were subsequently extracted by Westphal's phenol method. Furthermore, cross reactivity between endotoxins from the dialysate bacteria and E. coli J-5 was confirmed by the ELISA method. The titers of the standard anti-endotoxin antibodies obtained from a rabbit immunized by heat-killed bacteria were measured by immunoblotting, and the criterion for antibody positivity was decided on the basis of this result. After these preliminary experiments, the antibodies were measured with E. coli J-5 endotoxins as antigens in $101 \mathrm{HD}$ patiens and 21 normal volunteers by means of the ELISA method. As a result, $19 \%$ of the healthy controls and $26 \%$ of the HD patients using conventional membranes were antibody positive, while $60 \%$ of the patients using high-flux membranes were antibody positive.

安達 高久 大阪市立大学泌尿器科 个5 45 大阪市阿倍野区旭町 1-5-7 (06-645-2121) 
This value was significantly higher than those of the other two groups. These results strongly suggest that endotoxins in the dialysate may pass through membranes, especially high-flux membranes.

\section{緒言}

近年，重曹透析液やブドウ糖含有透析液の普及により 透析液の細菌およびエンドトキシンによる污染の増強が 観察され，問題となってきている。ささらにエンドトキシ ンは, 種々の条件下において分子量が 1 万程度のサブユ ニットに解離するため，これらの低分子エンドトキシン が患者の血液内に侵入している危険性が指摘されてい る. エンドトキシンは, 通常リムルステストという鋭敏 で特異性の高いアッセイによって測定される。しかしな がら，ここで問題とするエンドトキシンの小さなフラグ メントやサブユニットはこれらのアッセイに対し低感度 と考えられ1)，また血液中のエンドトキシンの測定には， アンチトロンビンIIIや $\alpha_{2}$-プラスミンインヒビターなど のさまざまな反応阻害物質が存在し2)，なお多くの問題 が残されている．また，TNF や IL-1の誘発によりエン ドトキシンの存在を証明する方法もあるが ${ }^{3,4}$ ，これらの 方法はエンドトキシンへの特異性に問題がある。そこで 今回の実験においては, enzyme-linked immunosorbent assay (ELISA) 法を使用して, 血液透析患者血液中の工 ンドトキシン抗体を測定し，これらの問題を検討した。

\section{方法}

1. 透析液中の細菌の採取，分離培責と同定およびエ ンドトキシンの抽出

まず直径 $0.45 \mu \mathrm{m}$ の pore size をもつアドバンテック 社製採取用フィルターに約 $200 l$ の透析液を濾過して フィルター表面に細菌を採取した。次に Pseudomonas agar（Difco）で分離培養を重ね, 日水 ID テスト, NF プレートを使用し同定を行った。その結果，Pseudomonas aeruginosa, Pseudomonas stetzeri および Enterobacter cloacae が同定された。これらの菌をホムアル デヒド殺菌し，さらにアセトン乾燥菌とした。

続いてWestphal ら ${ }^{5}$ の温フェノール・水抽出法を用い てエンドトキシンの抽出を行った。最初にアセトン乾燥 菌を蒸留水に浮かべ $67^{\circ} \mathrm{C} て ゙$ 加温し, 同温同容量の $90 \%$ フェノールを激しく擤汼しながら菌液に加えた。次に抽 出液を冷却後, 低温で遠沈して水層部分とフェノール層 に分離しエンドトキシンの抽出を行った。さらにフェ ノール層と不溶部分を水で再度加温抽出して回収率を高 め, 最後にエタノールで脱水, 抽出を行った。

2. 標準エンドトキシン抗体と ELISA 法による標準 曲線の作成

1）標準エンドトキシン抗体の作成

$2 \times 10^{8}$ cells $/ \mathrm{m} l$ に調整した Salmonella minnesota
$\mathrm{R} 595(\mathrm{Re})$ 株を 2,500 g，および 2,000 gの雌雄 2 羽の成 熟家鬼の耳の静脈より投与して免疫を行った。方法は, heat killed cell $0.25 \mathrm{~m} l$ より始め, その後, $0.25 \mathrm{~m} l$ ずつ 増量し, 週 2 回, 計 6 回の投与を行い，また免疫前と最 終免疫後 5 日目に全採血を行った。

2）標準エンドトキシン抗体の精製

家兔より得られた血清は, 硫安塩析法により精製を行 い,さらに Sephadex G25 カラムを使用し， 2 度のゲル クロマトグラフィーにより脱塩を行って, 標準エンドト キシン抗体とした。

3）標準エンドトキシン抗体の Immunoblotting によ る抗体価の検討

まず PBS に浸したセルロース膜に E. coli J-5 のエン ドトキシン $1 \mathrm{mg} / \mathrm{m} l$ のものを 1 滴のせ,次に $3 \%$ gelatin-PBS でblocking を行った。続いてセルロース膜 を Tween 20 入り PBS で $5 \sim 5^{7}$ 倍に希釈した標準抗体 およびコントロール血清中に入れ，さらに biotin 標識 protein A を，続いて alkaline phosphatase conjugated avidin（1,000 倍希釈）をセルロース膜に浸した。最後に para-nitrophenylphosphate acid disodium を添加し, 10 分後反応を測定した. その結果, 標準エンドトキシン 抗体は $5^{6}$ 倍まで抗原抗体反応が見られ, 一方, 免疫前の コントロール血清では, 各系列ですべて陰性であった(図 $1)$.

4） ELISA 法（図 2)

(1) $10 \mu \mathrm{g} / \mathrm{m} l$ の濃度に調整した抗原とするエンドトキ シンを $100 \mu l$, well 内に入れ, エンドトキシンの coating を行う. (2) $1 \%$ bovine serum albumin (BSA) を含んだ PBSを各 well $150 \mu l$ ずつ加え, 非特異的部位の blocking を行う. (3)抗体を測定する試験血清を必要な倍 数に希釈し, $100 \mu l$ を well に添加し, incubate 後溶液 を除去し, 反応を停止させるため PBS-Tween 20 にて 洗浄する. (4) biotin 標識 anti-human Ig class 抗体を, $100 \mu l$ well に添加し, 目的とする Ig class の特異抗 体を標識する. (5) biotin に非特異的かつ強力に結合する alkaline phosphatase conjugated streptavidin を 100 $\mu l$ well に添加する. (6)酵素基質として para-nitrophenyl phosphate (PNPP) $100 \mu l$ をell に加元, 室温 にて 25 分間反応させ, その後反応停止のため $5 \mathrm{~N}$ の $\mathrm{NaOH}$ を $50 \mu l$ ずつ加える. (7) 96 well の plate を, ELISA auto-reader で吸光度を $405 \mathrm{~nm}$ において測定す る. 


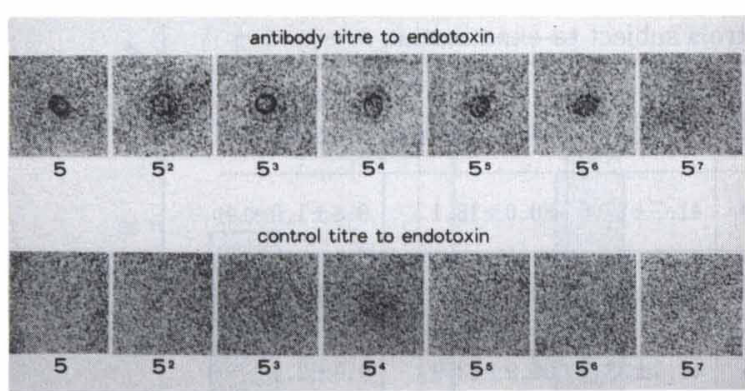

図 1 Immunoblotting for IgG antibody to endotoxin

\section{COATING OF LIPOPOLYSACCHARIDE ON PLATES \\ 96 well microtiter plates \\ $100 \mu$ l of LPS \\ overnight absorption}

2. BLOCKING NON-SPECIFIC BINDING SITES.

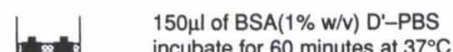

3. APPLICATION OF HUMAN SERUM

add human serum diluted with
$0.1 \%$ W/v BSA-PBS-Tween 20
incubate for $60 \mathrm{~min}$ at $37^{\circ} \mathrm{C}$

4. APPLICATION OF BIOTINYLATED ANTI-HUMAN Ig CLASS SPECIFIC ANTIBODY

add $100 \mu$ lof biotinylated antibody

5. APPLICATION OF ALKALINE PHOSPHATASE CONJUGATED STREPTAVIDIN

add $100 \mu$ l alkaline phosphatase conjugated streptavidin incubate for 30 minutes at $37^{\circ} \mathrm{C}$

6. APPLICATION OF P-NITROPHENYL PHOSPHATE

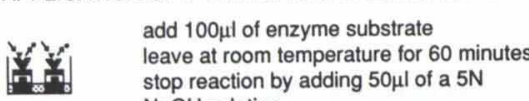
stop reaction by adding $50 \mu \mathrm{l}$ of a $5 \mathrm{~N}$ $\mathrm{NaOH}$ solution

7. MEASUREMENT AND PLOTTING OF A SEMILOGARITHMIC GRAPH

the optical density is measured at $405 \mathrm{~nm}$ plot the value on a semilogarithmic graph

図 2 ELISA technique for detection of antibody against endotoxin

\section{5）標準エンドトキシン抗体の検量線}

以上のことより，家患より得られた標準エンドトキシ ン抗体について, E. coli J-5 のエンドトキシンを抗原と して ELISA 法による検量線を作製した。 まず原液と 50 倍希釈液について縦軸に吸光度を, 横軸に希釈倍率（濃 度）をとり片対数グラフを作製した。これらのグラフは 共に抗原抗体反応の結果として S 字状曲線を描いた.今 回の実験では，すでに Immunoblotting 法により標準エ ンドトキシン抗体の $5{ }^{6}$ 倍希釈 $(15,625$ 倍希釈) 以上の濃
度において抗体の存在を確認している.そこで 50 倍希釈 のグラフ上の 4 倍の点 $(12,800$ 倍希釈 $)$ より高い濃度に おいては確実に抗体が存在するものと判断し，またこの 点における吸光度の值が 0.051 であることより,より確 実な 0.06 以上をもって抗体陽性の規準とした（図 3 ). 実際の患者の測定においては, 患者血清を 4 の累乗倍数 によって希䣋していき，まずこれが $\mathrm{S}$ 字状のグラフにな ることを確認した上で，抗原抗体反応が確実に起こって いると考えられるグラフのほぼ中央での点（実際には $4^{3}=64$ 倍希釈の点）における吸光度の值が 0.06 以上の ものを抗体陽性者とした。

6） E. coli J-5 のエンドトキシンの交差反応性の確認 対象とした血液透析患者のうち後ほど示す抗体陽性者 の中から 20 名を選び, E. coli J-5 のエンドトキシンと透 析液より分離した細菌由来のエンドトキシンの両者を抗 原として, ELISA 法における吸光度の関係を検討した。 結果としては, 両者は高い相関関係を示し $(\mathrm{Y}=0.67 \mathrm{X}+$ $0.12, \mathrm{r}=0.67, \mathrm{p}<0.01)$, E. coli J-5 のエンドトキシンが, 透析液由来のエンドトキシンと ELISA 法において強い 交差反応を示すことが証明された（図 4 ).

\section{対象}

以上の予備実験に引き続いて, ELISA 法により, E. coli J-5 のエンドトキシンを抗原として長期透析患者 血清中のエンドトキシン抗体を測定した. 対象は, 当院 および関連病院において 2 年以上の血液透析を受けてい るいわゆる安定期透析患者 101 名で, 過去 6 か月間に重 症の感染症, 重篤な肝機能障害および頻回の輸血歴を有 さない者を選んだ.さらに使用ダイアライザー別に, cellulose 系の low-flux 膜使用者 54 名と合成高分子系の high-flux 膜使用者 47 名に分けて検討した. また正常対 照者としてボランティア男女 21 名を選んだ. 各患者群間 には, 年齢を除く各パラメータに有意差を認めなかった (表)。また, 各群間の抗体陽性率を $\chi^{2}$ (カイ自乗) 検定 により危険率 $5 \%$ 以下において有意差検定を行った。

\section{結果}

全透析患者においては，101名中 42 名（42\%）が抗体 陽性であり, 一方正常対照者においては, 21 名中 4 名 (19\%) が抗体陽性であった。両群間には $\chi^{2}$ 検定におい て統計学的に有意差を認め $(\mathrm{p}<0.05)$, 透析患者には高 率でエンドトキシン抗体が存在することが判明した（図 5 ).さらに従来の low-flux 膜である Cuprophan 膜使 用者では，26名中 7 名 $(27 \%)$ が, Cuproammonium rayon 膜使用者では 28 名中 7 名 (25\%) が抗体陽性であ り, low-flux 膜群全体では 54 名中 14 名（26\%）が抗体 陽性であった。これらの值は正常対照群に比べ高值では あったが, 統計学的有意差は認められなかった（図6). 
表 HD patients and normal controls subject to examination

\begin{tabular}{|c|c|c|c|c|c|c|}
\hline \multicolumn{2}{|c|}{ Membrane group } & $\begin{array}{l}\text { Number of } \\
\text { patients }\end{array}$ & \multirow{2}{*}{$\begin{array}{l}\text { Age (years) } \\
55.9 \pm 12.9\end{array}$} & \multirow{2}{*}{$\begin{array}{c}\begin{array}{c}\text { Period of } \\
\text { dialysis } \\
\text { months }\end{array} \\
41.7 \pm 27.6\end{array}$} & \multirow{2}{*}{$\begin{array}{c}\begin{array}{c}\mathrm{BUN} \\
(\mathrm{mg} / \mathrm{d} l)\end{array} \\
80.0 \pm 18.1\end{array}$} & \multirow{2}{*}{$\begin{array}{c}\begin{array}{c}\text { S-creatinine } \\
(\mathrm{mg} / \mathrm{d} l)\end{array} \\
9.8 \pm 1.0\end{array}$} \\
\hline Low & Cuprophane & $\begin{array}{cc} & \mathrm{M}: 16 \\
26 & \mathrm{~F}: 10\end{array}$ & & & & \\
\hline group & $\begin{array}{l}\text { Cuproammonium } \\
\text { rayon }\end{array}$ & $\begin{array}{cc} & M: 16 \\
28 & F: 12\end{array}$ & $50.1 \pm 11.3$ & $45.2 \pm 20.0$ & $59.1 \pm 12.9$ & $10.2 \pm 1.7$ \\
\hline \multirow{2}{*}{$\begin{array}{l}\text { High } \\
\text { flux } \\
\text { group }\end{array}$} & PMMA & $\begin{array}{cc}28 & \mathrm{M}: 17 \\
\mathrm{~F}: 11\end{array}$ & $57.7 \pm 9.5$ & $48.3 \pm 33.9$ & $56.9 \pm 12.9$ & $9.9 \pm 2.1$ \\
\hline & EVAL & $\begin{array}{cc} & \mathrm{M}: 12 \\
19 & \mathrm{~F}: 7\end{array}$ & $48.2 \pm 8.6$ & $59.2 \pm 28.3$ & $59.4 \pm 16.8$ & $10.6 \pm 2.3$ \\
\hline \multicolumn{2}{|c|}{ Normal control } & $\begin{array}{cc}21 & \mathrm{M}: 12 \\
\mathrm{~F}: 9\end{array}$ & $31.7 \pm 7.9$ & - & - & - \\
\hline
\end{tabular}

PMMA : Polymethyl methacrylate, EVAL : Polyvinyl alcohol

$($ Mean $\pm \mathrm{SD})$

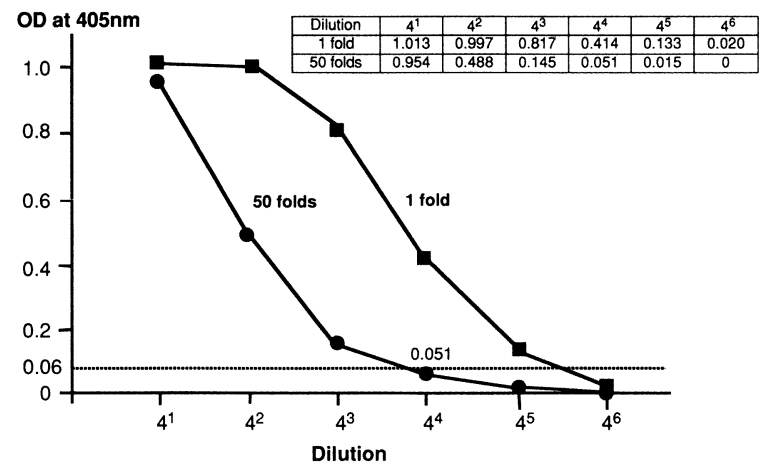

図 3 Standard curve of IgG antibody to endotoxin

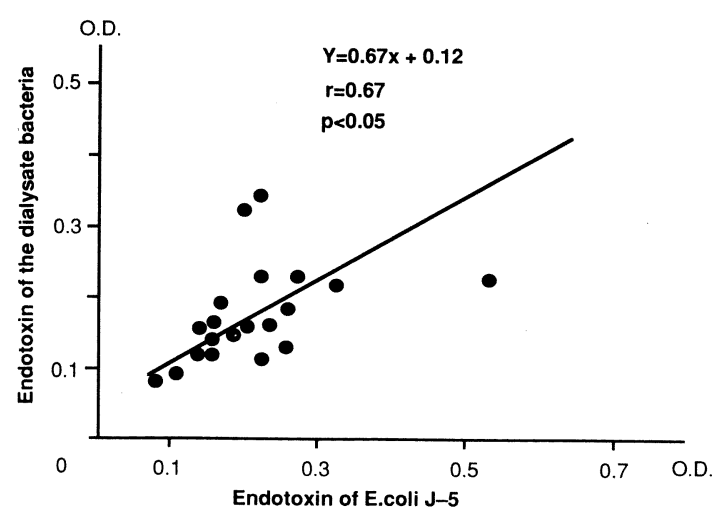

図 4 Cross reactivity between endotoxins from the dialysate bacteria and E. coli $\mathrm{J}-5$ in the ELISA method

しかしながら合成高分子膜の high-flux 膜使用群におい ては，PMMA 膜使用者では 28 名中 15 名（53\%）が， EVAL 膜使用者では 19 名中 13 名 $(68 \%)$ が抗体陽性で あり,さらに high-flux 膜群全体では 47 名中 28 名

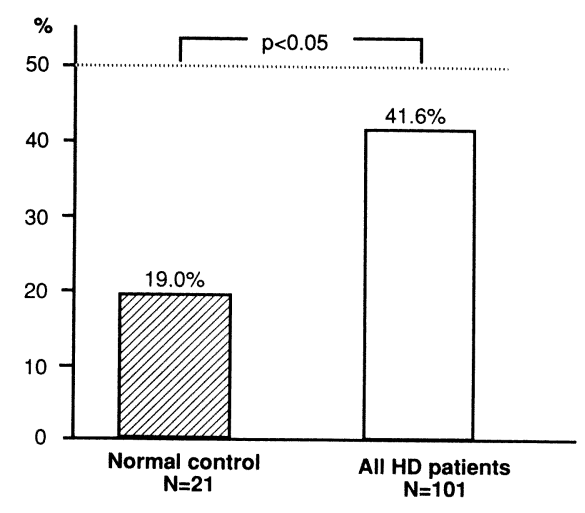

図 $5 \%$ endotoxin antibody positive in the healthy controls and all HD patients

(60\%)が抗体陽性であった。これらの值はいずれも正常 対照群に比較し有意に高値であった $(\mathrm{p}<0.05)$ (図 7 ). 考察

1. ELISA 法によるエンドトキシン抗体の測定 透析患者にエンドトキシン抗体が存在することは，す でに 1969 年に Gazenfield $ら^{6)}$ が受動的赤血球凝集反応 を用いて報告している.今回用いた ELISA 法は, avidinbiotin の強い親和性を利用し, さらに純度の高い antihuman IgG 抗体を利用することでより高感度で IgG 特 異性の高い抗体価を測定することが可能である。また今 回使用した E. coli J-5 (Re) という変異株は, コア部分 とリピドA部分を主体とする最も基本的な rough type の LPS 構造を持つ菌種である。これはエンドトキシン 抗体を作製するのに最も頻回に使用される菌種であり， 得られたエンドトキシン抗体は他の多くの LPS と交差 反応を示すことが認められている77. 


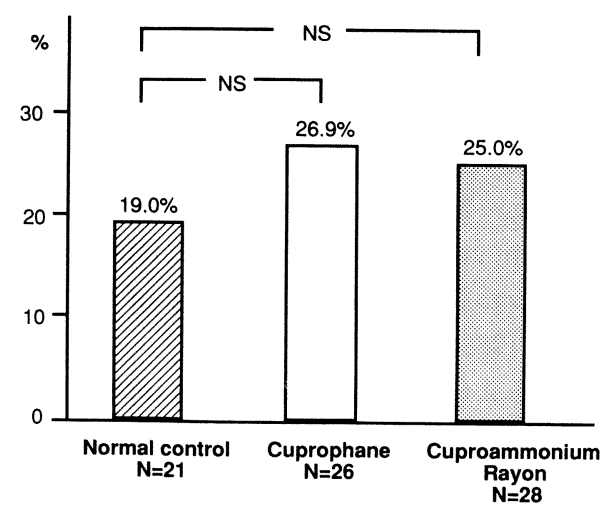

図 $6 \%$ endotoxin antibody positive in the conventional low-flux membrane group

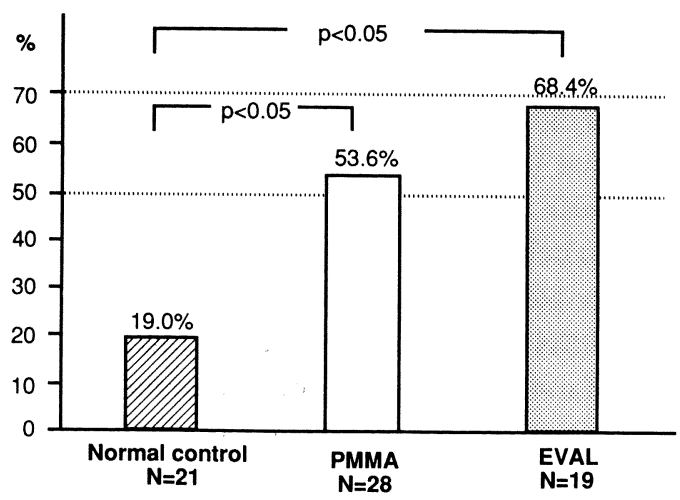

図 $7 \%$ endotoxin antibody positive in the high-flux membrane group

2. 透析患者のエンドトキシン抗体価と膜透過の可能 性

一般にエンドトキシンの体内への侵入経路としては， 細菌による感染症や外傷，手術および注射や検査などの 医療行為,さらには腸管より腸内細菌のエンドトキシン が吸収されることなどが考えられる，今回の結果におい て特に注目すべき点は, 正常対照者においても抗体陽性 者を認め, さらには正常対照群と low-flux 膜使用群の 間には抗体陽性率に有意差を認めず，一方 high-flux 膜 使用群との間には有意差を認めたことである。しかしな がら対象とした患者群は, 以上のようなエンドトキシン に暴露される機会や頻度において特に偏りがあるとは考 えられない. 従ってこの抗体陽性率の差は, エンドトキ シンに暴露される機会や頻度の問題ではなく, 透析膜の 性質の問題, ひいては膜のエンドトキシン透過性の差異 に基づくものであると考えるのが最も妥当と思われる. 近年, 長期透析患者に高率にみられる手根管症候群 (CTS) や透析アミロイドーシスの原因物質として $\beta_{2}$-microglobulin ( $\left.\beta_{2}-\mathrm{MG}\right)$ が注目されるようになり， これらの小分子蛋白の除去を目的に high-flux 膜が頻回 に使用されるようになってきた．エンドトキシンは通常 サブュニットが会合体を形成し，分子量が数十万〜数百 万の巨大分子を形成している。しかしながら，デオキシ コール酸ナトリウム (DOC) による処理を加えたりキ レート剤の存在など種々の条件下においてはサブュニッ トに解離し, 分子量が $\mathrm{S}$ 型 LPS で 10,000 20,000, R 型 LPS で 5,000〜 6,000 程度にまで小さくなるといわれ ている.さらにはエンドトキシンを超音波処理した結果 では, 通常の活性を持つエンドトキシンの細小単位は直 径が約 $150 \AA$ 程度の分子と推測されている（この場合分 子量は数十万に相当すると考えられる). 従って直接活性 を持った分子が膜を通過する可能性は極めて少ないと考 えられる、しかしながら上記に示したような何らかの要 因によって，あるいは自然に一部存在するより小さな工 ンドトキシンのフラグメントやサブユニットが，蛋白分 子の通過性を有するこれらの high-flux 膜を逆拡散や逆 濾過により通過することが十分に可能であると考えられ る ${ }^{8,9)}$. そして今回の実験は, 患者血液中のエンドトキシ ン抗体を測定することにより，患者血液中に侵入したエ ンドトキシンが免疫担当細胞を感作し, 抗体形成を促し ていることを示唆する結果を示すものと考えられた。さ らに Lonnemann ら ${ }^{3,4)}$ はエンドトキシンを透析回路内 に添加し血液回路内を循環させた単球より IL-1や TNF が産生されることよりエンドトキシンの膜透過の 可能性を主張している.

3.エンドトキシンの透析患者に及ぼす影響について エンドトキシンが透析患者の血液内に侵入し, 患者に どのような影響を及ぼしているかについてはほとんど明 らかにされていない.しかしながら，重症の合併症を伴 い血液透析だけではコントロールの困難な腎不全の場合 やしばしば観察される明らかな感染を伴わない原因不明 の発熱や, 単純な循環動態の変化では説明のつかない血 圧低下などにもエンドトキシンが関与している可能性が 推測されている.さらに William は, エンドトキシンで 感作したウサギの血清より得た免疫グロブリンのうち $\operatorname{Ig} M$ 分画にはエンドトキシンの致死毒性を中和する能 力が存在するが, 一方 IgG 分画にはこの中和能力のない ことを示し ${ }^{10)}$, 抗体の存在が必ずしも十分な生体防衛能 力を示すものではないことを示唆している.また in vitroにおいて, エンドトキシン, TNF, IL-1 および IFN を添加してマクロファージを培養すると, マクロファー ジより $\beta_{2}-\mathrm{MG}$ の産生が誘導されることが報告されてい $ろ^{11)}$.つまり本来は $\beta_{2}-\mathrm{MG}$ を除去する目的で作製され た high-flux 膜を使用することで，逆にエンドトキシン 
の侵入をまねきこれが患者の慢性の炎症状態をつくり上 げ, 結果として $\beta_{2}-\mathrm{MG}$ の産生を促しているという矛盾 が生じる可能性が存在するわけである。いずれにせよ, エンドトキシンの急性の有害作用を回避する意味でも, また慢性のおそらくは患者にとって不利益になるであろ うと予測される影響を避ける意味でも，血液透析におけ るエンドトキシンの侵入を阻止する必要があると考えら れる.そのためには透析液中のエンドトキシン濃度をで きる限りゼロに近いものにするか, あるいは透析液がダ イアライザーに入る直前においてエンドトキシンの侵入 を遮断するため, cut off point が少なくとも 5,000 以下 のフィルターを装着する方法が考えられている ${ }^{12}$. 以上, high-flux 膜使用透析患者におけるエンドトキシン侵入 の可能性と生体への影響について考察を述べたが，エン ドトキシンの透析患者に与える影響については, 今後の 問題として長期にわたる注意深い観察が必要であると考 えられた。

\section{結語}

1. 長期透析患者 101 名と正常対照者 21 名において, E. coli J-5 のエンドトキシンを抗原とし, ELISA 法に より血液中のエンドトキシン抗体を測定した。

2.このアッセイにおけるエンドトキシン抗体の陽性 率は正常対照群 19\%, low-flux 膜使用群 $21 \%$, highflux 膜使用群 $60 \%$ であり, high-flux 膜使用群の抗体陽 性率は前 2 者に比較し有意に高值であった $(\mathrm{p}<0.05)$.

3 . 以上の結果より, 特に high-flux 膜使用透析患者 においては, 透析液中のエンドトキシンが患者血液内に 侵入し, 様々な影響を与えている可能性が示唆された。

\section{文献}

1）本間遜, 岩永貞昭, 丹羽允, 吉田昌男: 内毒素. 医 歯薬出版, 東京, 1983

2) Nakamura $S$, Morita $T$, Harada $T$, Iwanaga $S$, Takahashi K, Niwa M : A clotting enzyme associated with the hemolymph coaglation system of horseshoecrab. Its purification and characterization. J Biochem 92 : 781-792, 1982

3) Lonnemann G, Bingel M, Floege J, Koch KM, Shaldon S, Dinarello CA : Detection of endotoxin- like interleukin-1-inducing activity during in vitro dialysis. Kidney Int $33: 29-35,1988$

4) Lonnemann G, Floege J, Schindler R, Behme T, Lenzner B, Shaldon S, Koch KM : Passage of cytokine-inducing E. coli fragments (CEF) through various hemodialysis (HD) membrane. Abstruct, 21st Annual Meeting of Am Soc Nephrol, 1988

5) Westphal O, Jann $\mathrm{K}$ : Bacterial Lipopolysaccharides. Methods Carbohydrate Chem $5: 83-91,1965$

6) Gazenfield GE, Eliahou HE : Endotoxin antibodies in patients on maintenance hemodialysis. Israel J Med Sci 5 : 1032-1036, 1969

7) Mutharia LM, Crockford G, Bogard WC, Hancock RW : Monoclonal antibodies specific for $\mathrm{E}$. coli J-5 lipopolysaccharide : Cross reaction with other gram-negative bacterial species. Infect Immun $45: 631-636,1984$

8) Stiller S, Mann H, Brunner H : Backfiltration in hemodialysis with highly permeable membranes. Contr Nephrol 46 : 23-32, 1985

9) Man NK, Ciancioni C, Faivre JM, Diab N, London G, Maret J, Wambergue FP : Dialysis-associated adverse reactions with high-flux membranes and microbial contamination of liquid bicarbonate concentrate. Contr Nephrol $62: 24-34,1988$

10) McCabe WR, DeMaria A, Berberich H, Johns MA : Immunization with rough mutant of Salmonella minnesota: Protective activity of $\operatorname{IgM}$ and IgG antibody to the R595 (Re Chemotype) mutant. J Infect Dis $158: 291-300,1988$

11) Knudsen $P$, Leon J, Ng A, Shaldon S, Floege J, Koch $\mathrm{K}$ : Hemodialysis related induction of $\beta_{2}-$ MG and IL-1 synthesis and release by mononuclear phagocytes. Nephron $53: 188-193,1989$

12) Tutunjian RS: Pyrogen removal by ultrafiltration. Endotoxins and their detection with the Limulus Amebocyte Lysate test. Alan R. Liss, Inc., New York, $150:$ 319-327, 1982 